\title{
Understanding of the Socio-Economic Benefits of Rural Home Based Enterprises (HBEs) Through the Framework of Livelihood Resources
}

\author{
Masud Ur Rashid \\ Department of Architecture, Southeast University, Dhaka, Bangladesh.
}

Email: masudurrashid@yahoo.com

ARTICLE INFORMATION

Received: February 02, 2018

Revised: May 29, 2018

Accepted: June 28, 2018

Published online: July 02,2018

\section{Keywords:}

Socio-Economic benefits, Home-Based Enterprise, Livelihood Resources, Rural Housing, Rural poverty, Permanent and Floating households

\begin{abstract}
This article investigates the socio-economic benefits of Home Based Enterprises (HBEs) within the settings of rural housing in Sirajganj, Bangladesh. Households' livelihood resources are engaged and affected widely by the HBEs and reciprocally the HBEs are also affected by them. Some households practice HBE only for their subsistence and some are involved for their household development. A major number of family members are engaged with the HBE. When HBE is practiced within the rural households, the livelihood receives some extended dimensions of socio-economic benefits. These benefits are studied for the six selected cases, identified as permanent and floating households. The selected case study HBEs are analyzed with reference to the analytical scale factors of livelihood resources. A comparison of the socio-economic benefits of the cases of permanent and floating homesteads context is drawn through the data analysis.
\end{abstract}

DOI: http://doi.org/10.15415/cs.2018.61003

\section{Introduction}

In Bangladesh, the poverty rate is $24.3 \%$ of the total population, and around 80 percent of them live in rural areas (World Bank 2018, BBS 2010). In this pervasive poverty, a dwelling or a house has not always been seen just as a place for living. Home-based Enterprises (HBEs) are the small enterprises that are performed within the premise of households, mainly operated by the household members, to achieve the economic solvency. Although HBEs studied in urban areas in developing countries (Strassmann, 1987; Tipple, 1993; Ghafur, 2001) studies rarely investigate the impacts of HBEs on rural housing. Household acts as the primary economic decision making unit in rural as well as in urban areas. Rural HBEs are perhaps more intricately involved with the concerned households in engaging their social, physical and economic resources than urban types. HBEs hold a central place in the survival of the rural poor and households. This study, therefore, seeks to search and develop a framework that examines HBE within the overall household survival initiatives. The livelihood resources contain several 'asset' or 'capital' that are concerned largely with household-based productive activities (Conway 2002, NAFRI 2005). Capital and asset are mainly business terms.
They may be used in other contexts also, depending on the situation, and there are several variations of each term. Not only the physical objects such as buildings and machines are considered assets, but intangibles objects are also considerable as assets. Department for International Development (DFID) reported five forms of assets or capital available in households. They are: 'human capital', 'natural capital', 'financial capital', 'physical capital' and 'social capital'. The extent to which these five assets operate in a given livelihood activities is manifested through the asset pentagon. The 'Asset Pentagon' is a visual representation of information that developed the important inter-relationships between the various assets (DFID 1999).

Workability, any skills, knowledge, ability to labour, leadership potential, good health etc. are represented by 'Human capital'. These makes people enable to pursue different livelihood strategies and achieve their livelihood objectives. 'Human capital' is a factor of the amount and quality of labour available at a household level. Natural resources such as, land, water, forests, natural environment quality, river erosion etc. are the part of 'Natural capital'. It has special importance for those who derive their livelihoods (all or partial) from natural resource-based activities. Possibilities of natural calamity is also an 
important part of natural capital. 'Financial capital' is probably the most adaptable among five categories as it can be converted into other types of capital or it can be used as a direct mode of livelihood outcomes. It includes the direct financial solvency of a household. Affordable transport, settlement and shelter, sanitation and adequate water supply etc. are the part of 'Physical capital'. These are the producer and basic infrastructure that needed to support livelihoods. Social resources such as social relations, affiliations, associations and networks etc. are the part of 'Social capital'.

\section{Methodology}

To make an understanding of the Socio-Economic Benefits of Home Based Enterprises (HBEs) through the Framework of Livelihood Resources in the specific rural context is the objective of this paper. Study focuses arei) Socio-economic benefits of different HBEs in a specific rural context; ii) The nature and extent of rural HBEs and iii) A comparative analysis of livelihood resources in permanent and floating households. The study has been designed in two parts: a literature review part and an empirical part based on field survey in the local context. The research methodologies employed in these two parts are explained below. Relevant literatures have been reviewed to determine the key concepts and developed an understanding to prepare a theoretical background in order to carry out the field survey and analyze the data. Two different contexts of 'permanent' (people of old traditional village) and 'floating' (river erosion effected people) households were considered from two villages in Sadar and Kazipur Upozilas in the district of Sirajganj in Bangladesh. The cases have been selected through a reconnaissance survey of the home based enterprises in the rural area of the district of Sirajgonj. Physical observation, questionnaire survey, photographs and drawings are taken to analyze the cases. The features of the permanent and floating households in this research are as follows:

Permanent households contain the permanent dwellers (people who live in a fixed location for more than three generations). Two adjacent villages approximately 10 (ten) kilometers distant from the Sirajganj District town are surveyed as the context of permanent households. Name of the villages are Bagbati and Pipulbaria within the Sadar Upozila of Sirajganj. Both are old village with good number of established inhabitants.

Floating households contain the floating dwellers (people who are displaced due to river erosion and live in social and economic hardship). They have mainly established their houses in riverside villages by taking land on a rental basis. Three adjacent villages named Shimanto-bazar, Ghati Shuvogachha and Baikhola are considered for the context of floating households for this study. They have a distance of twenty kilometers from the Sirajganj town. In these two different contexts, differences were found in the type and nature of home-based enterprises operated by permanent and floating households. It also suggests that the devastating impacts of river erosion on shelter affects dwellers' adaptive response to living and livelihood manifested in the economic diversification of home based enterprises. Considering the potential depth of case histories three $\mathrm{HBE}$ cases from the permanent and floating homesteads are selected to analyze them with respect to the livelihood resources.

Table 1. List of selected HBE cases for livelihood analysis in different levels.

\begin{tabular}{|l|l|l|}
\hline $\begin{array}{l}\text { Homestead } \\
\text { Type }\end{array}$ & $\begin{array}{l}\text { Selected } \\
\text { cases }\end{array}$ & Description \\
\hline \multirow{5}{*}{$\begin{array}{l}\text { Permanent } \\
\text { households }\end{array}$} & Handloom & $\begin{array}{l}\text { Making 'lungi' with manual loom. Sultan Mahamud is the owner of this HBE. He is doing this since 2001 in } \\
\text { his old household on his own land in the village of Bagbati. There are six members in his family. }\end{array}$ \\
\cline { 2 - 4 } & $\begin{array}{l}\text { Pottery } \\
\text { and } \\
\text { carpentering }\end{array}$ & $\begin{array}{l}\text { Making things by mud. Sri Jon Kumar Paal is the owner of this HBE. It is their family profession that he } \\
\text { carried on from the ancestry. His single family consists of four members. }\end{array}$ \\
\hline \multirow{4}{*}{$\begin{array}{l}\text { Floating } \\
\text { households }\end{array}$} & $\begin{array}{l}\text { Shib Shankor Kawali is the owner of this household and he is engaged with carpentering. His daughter } \\
\text { and daughter are the only members of the family. }\end{array}$ \\
\cline { 2 - 4 } & Egg supply & $\begin{array}{l}\text { Collecting of eggs from villagers and supply them to market. Mokbul Hossain is the owner of this HBE. In } \\
\text { the present homestead his business is being operated since 2004. Because of the river erosion he had to move } \\
\text { his homestead at the present location. There are eleven members in his family. }\end{array}$ \\
\cline { 2 - 4 } & Tailoring & $\begin{array}{l}\text { Farming of cows for milk. Azahar Ali is the owner of the dairy farm. In the present location the homestead } \\
\text { has been shifted in 2004. Azhar has five members in his family. }\end{array}$ \\
\hline & $\begin{array}{l}\text { Making clothes by sewing machine to meet peoples order. Habibur Rahman is the owner this HBE and he } \\
\text { is doing it since 1992. At the current location the homestead has been shifted in 2004. His family consists of } \\
\text { four members. }\end{array}$ \\
\hline
\end{tabular}


Selected cases are analyzed through livelihood resources framework and plot the value of each asset in the asset pentagon to receive an understanding of their socio-economic benefits. Variation in people's access to different assets are conceptually shown by the shape of the asset pentagon. The center point of the pentagon (where the lines meet) represents zero access to assets while the outer perimeter represents maximum access. By this concept, different shaped pentagons are achieved from the different HBEs of this study. Each of the attributes is valued by any of above (Table 2) five measuring units and achieved a resultant value.

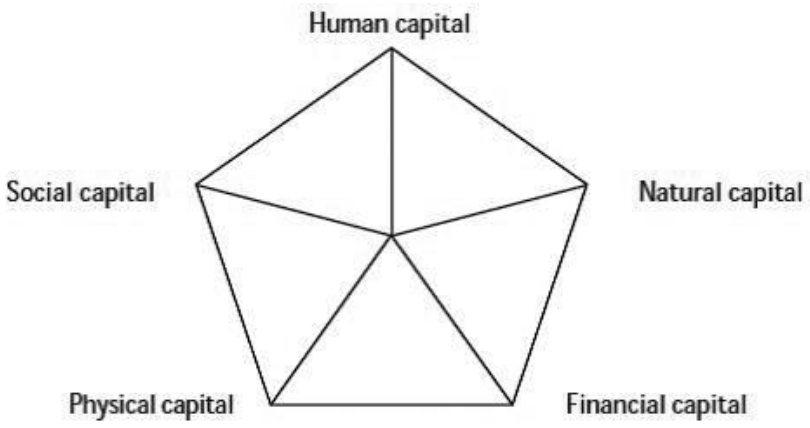

Figure 1. The asset pentagon

Table 3. Required nature of equipment and spaces for the HBE cases.
Table 2. Values for the determinants of livelihood resources.

\begin{tabular}{cc}
\hline Level & Numeric value \\
\hline Very low & 1 \\
Low & 2 \\
Medium & 3 \\
High & 4 \\
Very High & 5 \\
\hline
\end{tabular}

\section{Type, Nature and Extent of HBEs}

The selected HBE cases of this study are different in type and nature. It is found that all the HBE cases are depended not only on the spaces or house-forms. They are also depended on the availability of light or heavy equipment for producing or processing the product. Most heavy and easily non-transferrable equipment and machineries are used in the $\mathrm{HBE}$ cases of permanent households. The HBEs of floating households normally do not use heavy machineries. There are cases that are not machine-dependent. They are mainly space oriented. Space is the main resource to operate these HBE cases. This space might be open, semi-open or often indoor built-form. Different types of HBEs have different considerations with the livelihood resources. A list of this sort of HBEs is as follows:

\begin{tabular}{|c|c|c|c|}
\hline $\begin{array}{l}\text { Homestead } \\
\text { Type }\end{array}$ & HBE case & Nature of required equipment and tools & Nature of required space \\
\hline \multirow{3}{*}{$\begin{array}{l}\text { Permanent } \\
\text { Homestead }\end{array}$} & Handloom & $\begin{array}{l}\text { Totally depended on looms (tant) and other } \\
\text { supporting machines that need separate house-forms } \\
\text { and permanent establishment of the household. A } \\
\text { good amount of initial investment is required to start } \\
\text { this type of HBE. }\end{array}$ & Required semi-shaded and shaded space. \\
\hline & Pottery & $\begin{array}{l}\text { Though initial investment is high in this } \mathrm{HBE} \text { case } \\
\text { equipment remain essential. Motorized wheel for } \\
\text { making the pots from clay and a giant burner (chulli) } \\
\text { which is not easily transferrable are the required } \\
\text { equipment for this HBE. }\end{array}$ & $\begin{array}{l}\text { Required wide open space to dry the raw } \\
\text { pots under sunlight. Also needs sufficient } \\
\text { storage for ready products. }\end{array}$ \\
\hline & $\begin{array}{l}\text { Spinning and } \\
\text { carpentering }\end{array}$ & $\begin{array}{l}\text { Very small and handy equipment are required for this } \\
\text { HBE case. A manual spinning machine (Charka) is } \\
\text { the main equipment for spinning and carpentry tools } \\
\text { are the equipment for carpentering. }\end{array}$ & $\begin{array}{l}\text { Small open court( } u \text { than) is used for both the } \\
\text { spinning and carpentering. }\end{array}$ \\
\hline \multirow{3}{*}{$\begin{array}{l}\text { Floating } \\
\text { Homestead }\end{array}$} & Egg supply & $\begin{array}{l}\text { No such machines or equipment is required other } \\
\text { than some storage case and measuring scale. }\end{array}$ & $\begin{array}{l}\text { Only a shaded space is used as the storage } \\
\text { and supply centre for this HBE. }\end{array}$ \\
\hline & Dairy & $\begin{array}{l}\text { Livestock is the main resource rather than any } \\
\text { equipment or machineries. }\end{array}$ & $\begin{array}{l}\text { Different spaces for daytime and night time } \\
\text { is required for the livestock. }\end{array}$ \\
\hline & Tailoring & $\begin{array}{l}\text { Sewing and embroidery machines which are easily } \\
\text { transferrable are the equipment that are required for } \\
\text { this HBE. }\end{array}$ & $\begin{array}{l}\text { A shed for the total work process and a semi- } \\
\text { open space for customers sitting is required }\end{array}$ \\
\hline
\end{tabular}


Selected HBE cases are considered for detail analysis within the framework of the livelihood resources in the next two subsequent sections.

\section{Activities and Benefits of HBEs in Permanent Households through the Framework of Livelihood Resources}

This section describes the role of different assets within the livelihood resources of the selected cases.

\subsection{Human Capital}

Two types of 'human capital' are employed inthe HBE of Handloom.

i) Family members who works without any wages. They are six in numbers and both male and female.. Male members are involved with the management, marketing, sales and sometimes physical labour as Tanti (who operates the machine). On the other hand, female members are engaged to process shuta(yarn) for the cloth by using machine and manual labour simultaneously. Female workers manage their time beside the regular household activities like cooking, washing, housekeeping etc.

ii) People other than the family members who works for wages. Male workers work at tant(machine used for making cloth) and females work into houses with the family members. There are 25 external workers in total in this HBE which is $81 \%$ of the total human capital. Female workers mainly engage with the pre-production works like yarn processing and dyeing (Figure 2).

It is a common practice in that village, to employ professional labours and giving standard wages. The amount of engaging external manpower represents the volume and the strength of the HBE. Human capital engaged in Pottery consists of the family members. It is a profession that they are carrying

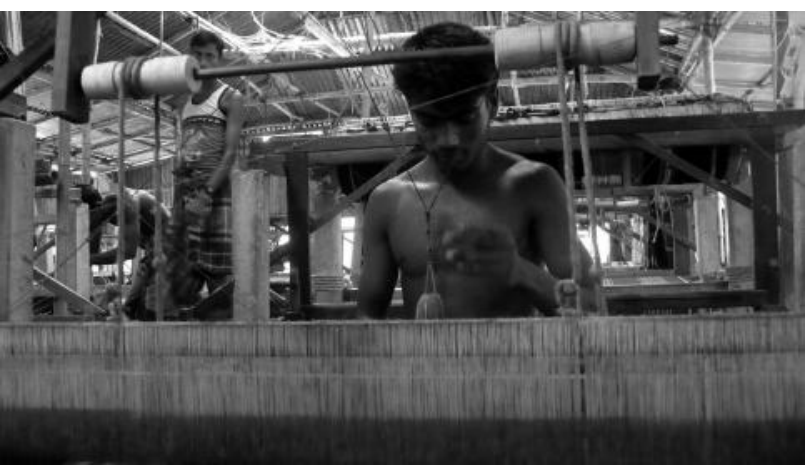

(a) on from their ancestry. Every family member both male and female is working in the total process of production. Generally the female members work inside the house and the male members are outside the house (Figure 3). Every one of the family is a worker of the HBE and are skilled enough to handle their job though they have no formal education. Human Capital engaged in Spinning and Carpentering also consists of only family members. The father Shib Shankar is engaged for carpentering without any helping hand and the daughter Beauty is doing the spinning alone (Figure 4). The daughter doing the spinning for the looms situated nearby the village. The father Shib Shankar makes small furniture and sells them into weekly ' haat'. Though it is very hard job to work such carpentering without any helping hand but Shib Shankar does so to save the wages for paying. If we look at the percentage of total labour it is found that $100 \%$ member of the household of spinning and carpentering is engaged with the HBE but in reality they are only two in number. In fact, two types of enterprises are involved here. Though they are skilled with their own premise of work, in absence of any one of them the whole enterprise will be collapse.

The human capitals are not same in these three selected case. They are widely varied in number. Be that as it may, when we break down their quality it is relying upon their expertise, learning, quality, capacity to work and great wellbeing as opposed to their number. These determinants are varied in these cases. For example, in Pottery, the total manpower is only four in number but they are well skilled and expert for this $\mathrm{HBE}$. On the other hand, Handloom has to hire wagebased labours which sometimes affect the consistency of production. The strength of human capital of Pottery is higher than the Handloom. Once more, on account of Spinning and carpentering the human capital is little in number and as they are worked by single individual their capacity to work is in a helpless circumstance. This is the reason their incentive in the rating is lower than the other two cases.
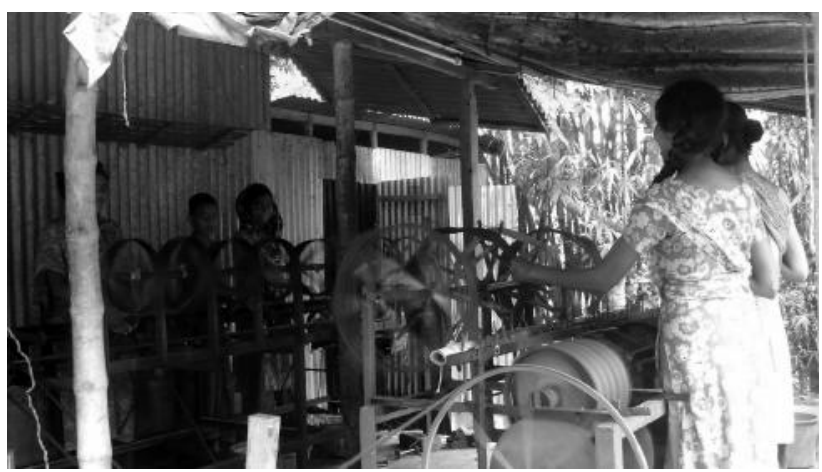

(b)

Figure 2 (a): In Handloom, male workers are working in the factory house and (b): The female workers are working in the inner courtyard. 


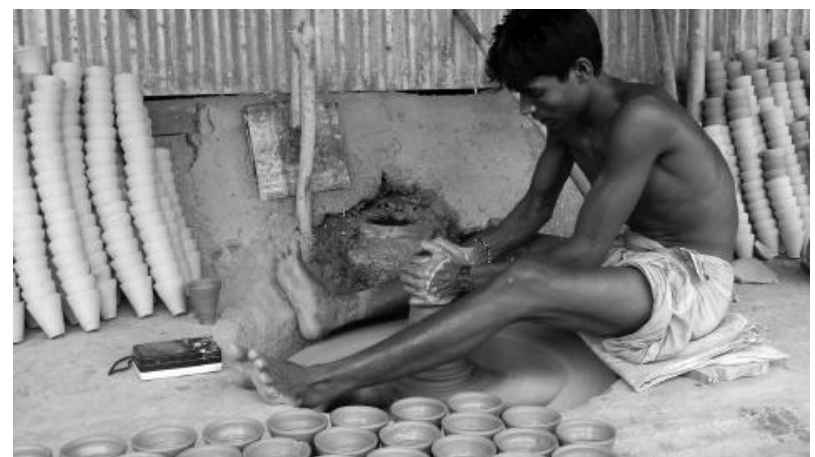

(a)

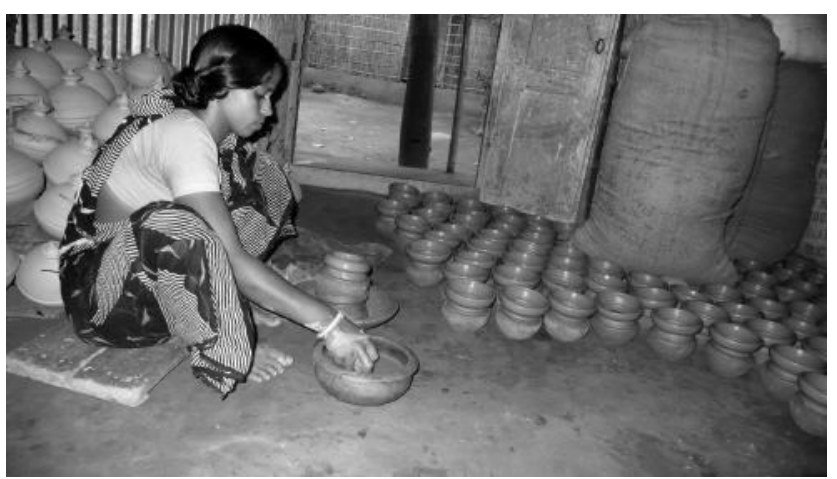

(b)

Figure 3(a). In Pottery, male family member is working at the external work space and (b): The female member is working inside the house.

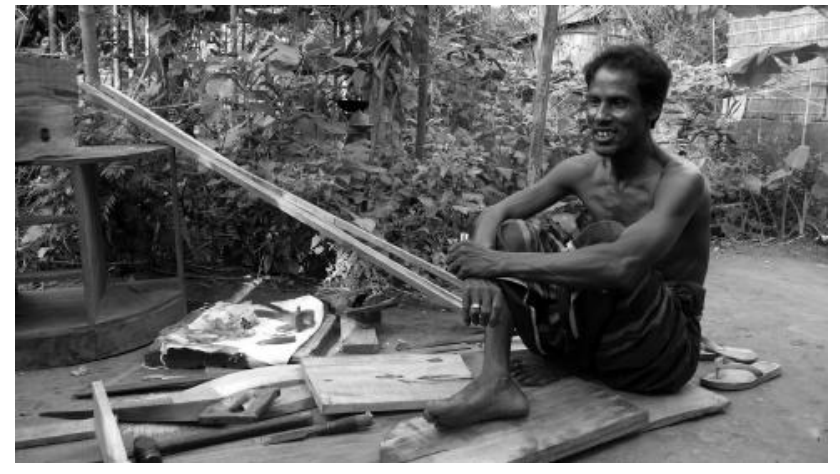

(a)

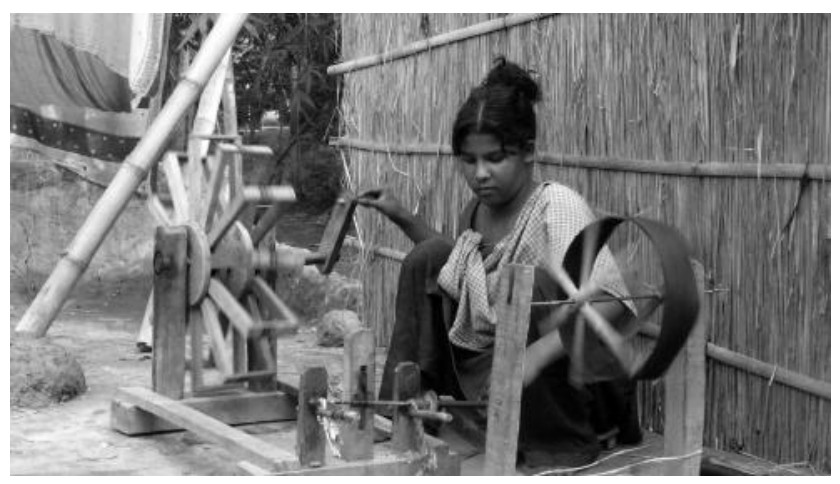

(b)

Figure 4(a) and (b). In Spinning and Carpentering, Shib Shankar and his daughter works for different HBEs within a single homestead.

\subsection{Natural Capital}

In all $\mathrm{HBE}$ cases, the households are not in any vulnerable situation or in threat of any natural disaster other that the annual monsoon. There is no threat of river erosion possibilities in this village. All the households are well prepared for the annual flood hazarded. Respecting the vulnerability context homesteads of the selected three cases of this context are relatively safe. Dependence on nature comes in many forms as raw material for production. The HBE of Handloom is operated manually without electricity. The sun is acting as the natural capital as the source of light and heat. For this natural capital Sultan

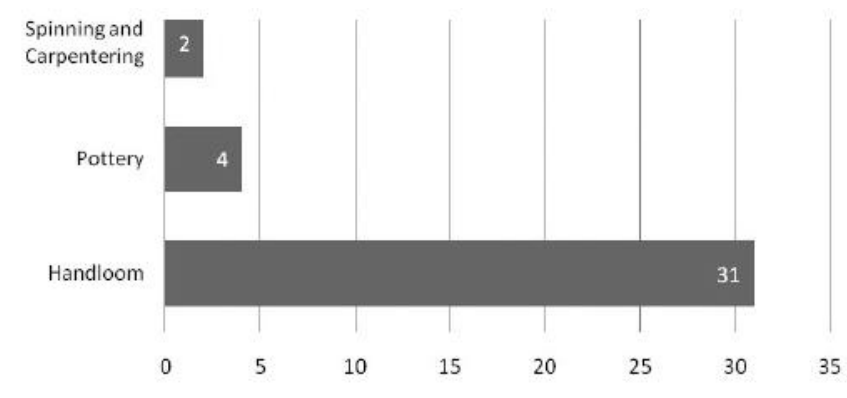

(b)

Figure 5. The values of Human capital and (b): The total manpower engaged in the selected HBE cases in the permanent households. 
(the owner of the HBE) do not have to pay. In the HBE of Pottery the earth clay is used as the raw materials for production and they are dried under the direct solar heat. For the earth clay Sri Jon Kumar Paal (the head of the household) has to pay money. They collect suitable earth from the short distant village and in most of the cases they bring them to their house by themselves with manual labour. The earth and the sun both are used as the natural capital which play vital role over these $\mathrm{HBE}$ cases.

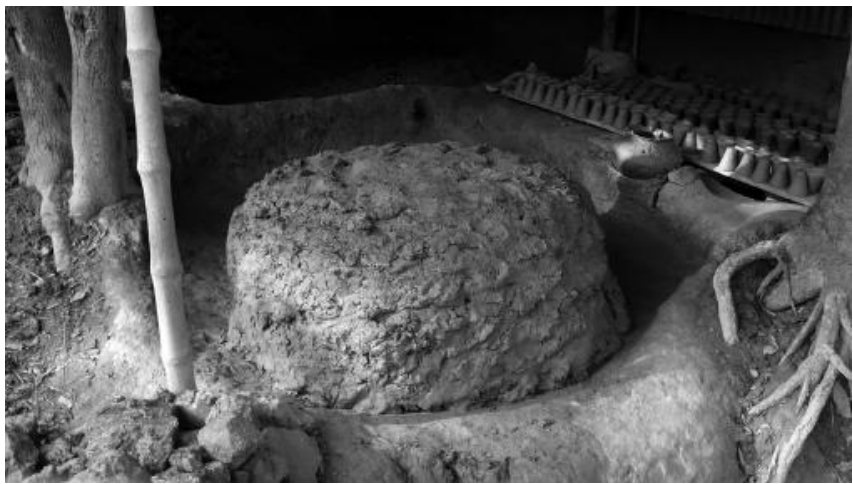

Figure 6. Earth clay is stored for production in Pottery.

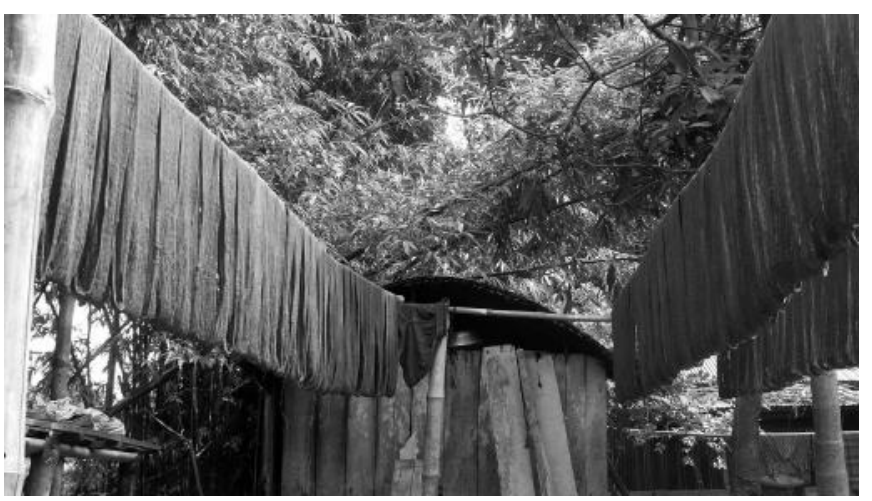

Figure 7. Sunlight is used to dry the raw materials in Handloom.

\subsection{Financial Capital}

Financial capitals are involved in the HBE of Handloom in two ways. They are:

i) Stock of raw materials. Due to the fluctuating rate of raw material Sultan always reserve a stock for at least three months' production. An amount of money is always engaged for this purpose.

ii) Stock of product. Sultan keeps a stock of his finish product before their sales. Finish product (i.e. lungi) made liquid money flow to the HBE. Regular cash flow is made by regular production. Sultan maintains this cycle in his business.
Thus he creates a three step Financial Capital such as- a) Stock of raw materials, b) Stock of finish product and c) Liquid money flow. Monthly income of this household is around Tk. 23,000 of which 90\% comes from the HBE. Another 10\% comes from their agricultural lands which are leased out. Sri Jon Kumar Paal maintains two types of stock for the Financial Capital of his HBE of Pottery. They are:

i) Stock of raw materials. This is mud not has a significant monetary value.

ii) Stock of finish product. All through the year it has a very good amount of stock of finish product of the HBE.

The regular inflow of money of this $\mathrm{HBE}$ is not so high because of two reasons:

a) All through the year the products (pots made by clay) are not sold out evenly. During some specific season like Bangla New Year's mela the demand of these types of products are high.

b) The unit price of such product is very low and that is why the cash flow also reflects the poverty of the household.

Jon Kumar Paal has a monthly household income of only Tk. 5800 in an average and he does not have any other source of income. For Spinning and Carpentering the HBEs are the only sources of income of this household and the level of Financial Capital for Shib Shankor and his daughter Beauty is very low. Beauty collects yarn (shuta) from the loom factory and spins them into rolls with a manual machine. Yarns and plastic rolls are the properties of loom factory. Beauty gets wages according to the quantity of rolls full of yarn. The wage is Tk. 20 per 100 rolls and she can spin a 100 rolls in a single day. Shib Shankor has a very small capital to invest. He sells furniture that he has made all through the week in the weekly haat and maximum amount of this money is spent for buying timber for his next week production. Both Shib Shankor and his daughter have a very poor stock and liquid money flow available for their HBEs. There are major differences found in financial capital in these three selected HBEs that shows the financial status of them.

Among the three households, Spinning and Carpentering has the lowest value of Financial Capital with the lowest monthly income and underneath the poverty line considering less than one dollar per day income (World Bank, 2008). Pottery is below the poverty line considering US dollar 2.5 (considering around $\mathrm{Tk}$. 80 for US dollar 1.0) per day income. On the other hand, Handloom has comparatively solvent financial status in the context. 


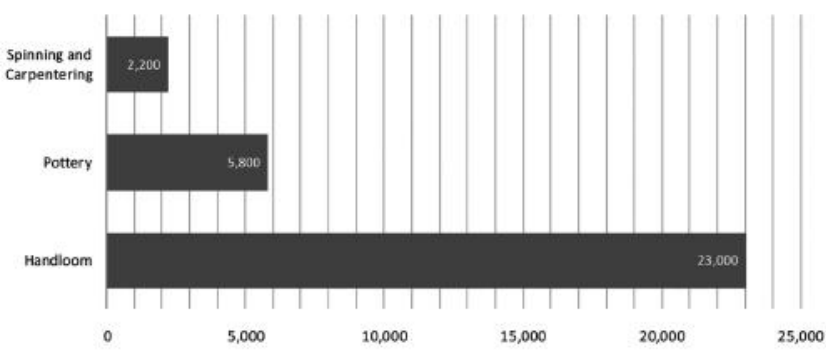

Figure 8. Graph shows the monthly income (in BDT) in the selected $\mathrm{HBE}$ cases in the permanent homesteads.

\subsection{Physical Capital}

Sultan has two types of physical capital for his HBE of Handloom including his homestead.

i) Established buildings for the HBE and for the family living. It is an old homestead for their living and he just developed to make them suitable for his HBE.

ii) For the HBE Sultan has twenty handlooms and some other accessories that can make the total enterprise running smooth.

Sultan can afford the transportation costs of his product to deliver them to the local haat and inter-district haat. Water from tube-well for drinking and sanitation was used by them as the total village is used to. There is only one separate toilet for the labors and on toilet for the family use. The only source of power is the PalliBiddut (rural electricity). All the machines are manual here and does not need any electricity to run. The need for electricity is for light during cloudy weather and music player for the labors' refreshment. From last decade, cellular phone is very easily accessible for everyone in every village of Bangladesh. Sultan makes his business communication at several stages through cellular phone.

As an elder villager Jon Kumar (of Pottery) has well established homestead with house form for the family living and the HBE. Large open space is required for pottery which they have. During interview when Jon Kumar was asked whether the space is adequate or not, he answered "potters space will never appears to be adequate to them". They have shed for the raw materials and finish products and a giant burner. This burner is being shared by two or three households (Figure 9). They need transport like rickshaw-van and vutvuti(locally made motorized van) to transport their products. Sometimes they carry them by themselves through human labour. They have only one toilet for their use and one tube-well for water for drinking, sanitation and making clay as the raw material. For the household use they have an electricity connection from the PalliBiddut. But the machines do not require any electricity for operation.

Shib Shankor(of Spinning and Carpentering) sold his old house that was made by CI sheet to arrange money for the marriage of his elder daughters. After that he has a poor house made by thatch wall and CI sheet roof for him and his daughter Beauty which was previously used as their kitchen (Figure10). Now this house is used for their living and they use an open space as kitchen. The small open court (uthan) is used for spinning and carpentry works. They do not use any vehicular transport for their HBEs. There is a tube-well used as the source drinking water and water for sanitation and a clean toilet inside their homestead. These HBEs do not required any electricity and do not has electricity connection from the PalliBiddut that maximum homesteads of this village have. The affordability of energy is low of this homestead.

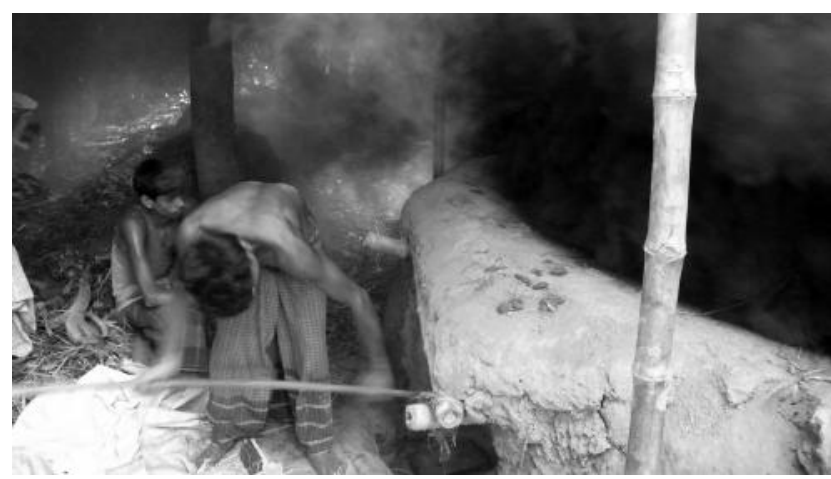

Figure 9. The shared burner of the HBE of Pottery.

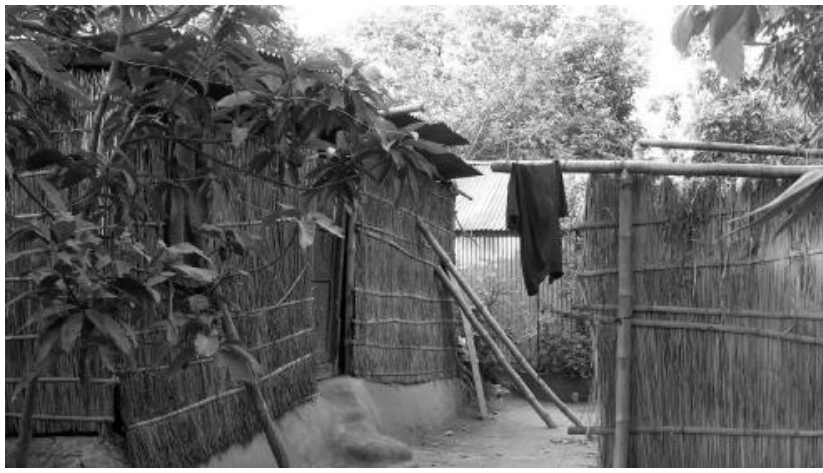

Figure 10. The only house form of Spinning and Carpentering.

The five main components of Physical capital are analyzed with respect to the selected three HBE cases of the permanent homesteads in the following table:

Difference in the physical capital values of the selected three cases of this context shows a remarkable figure. The Spinning 
Table 4. Comparison among the components of Physical capital of the HBE cases of Permanent homesteads.

\begin{tabular}{|c|c|c|c|}
\hline $\begin{array}{l}\text { Components of Physical } \\
\text { capital }\end{array}$ & Handloom & Pottery & Spinning and Carpentering \\
\hline $\begin{array}{l}\text { Buildings and } \\
\text { settlement }\end{array}$ & $\begin{array}{l}\text { Separate houses for family living } \\
\text { and the factory. Factory is well } \\
\text { equipped with machineries. } \\
\text { Houses are made by CI sheet } \\
\text { wall and roof. }\end{array}$ & $\begin{array}{l}\text { Open space for drying the products } \\
\text { under sun, shared burner, shed and } \\
\text { houses for family living and storage. } \\
\text { Houses are made by CI sheet wall } \\
\text { and roof. }\end{array}$ & $\begin{array}{l}\text { Only a single house made by } \\
\text { thatched wall and CI sheet roof } \\
\text { for living. Open space without } \\
\text { shed is used as the working place. }\end{array}$ \\
\hline Transportation & $\begin{array}{l}\text { Motorized vehicle and rickshaw } \\
\text { van both are used to transport } \\
\text { the raw materials and finish } \\
\text { products. }\end{array}$ & $\begin{array}{l}\text { Human labour is used to carry the } \\
\text { raw materials and rickshaw van to } \\
\text { transport the finish products. }\end{array}$ & $\begin{array}{l}\text { Manual labour is used frequently } \\
\text { and rickshaw van is used } \\
\text { occasionally. }\end{array}$ \\
\hline $\begin{array}{l}\text { Water supply and } \\
\text { sanitation }\end{array}$ & $\begin{array}{l}\text { Separate tube-well for drinking } \\
\text { water and sanitary latrine for the } \\
\text { labours and household use. }\end{array}$ & $\begin{array}{l}\text { One tube-well for drinking water } \\
\text { and daily uses and one sanitary } \\
\text { latrine for the household. }\end{array}$ & $\begin{array}{l}\text { One tube-well for drinking water } \\
\text { and daily uses and one sanitary } \\
\text { latrine for the household. }\end{array}$ \\
\hline Affordable energy & $\begin{array}{l}\text { Non-renewable energy from } \\
\text { PalliBiddut for household use. } \\
\text { Electricity is not required to } \\
\text { operate the equipment of the } \\
\text { factory. }\end{array}$ & $\begin{array}{l}\text { Non-renewable energy from } \\
\text { PalliBiddut for household use. } \\
\text { Electricity is not required to operate } \\
\text { the equipment for HBE. }\end{array}$ & No electricity connection. \\
\hline Communications & $\begin{array}{l}\text { Cellular phone is used to } \\
\text { communicate frequently. }\end{array}$ & $\begin{array}{l}\text { Cellular phone is used to } \\
\text { communicate frequently. }\end{array}$ & Very low use of cellular phone. \\
\hline
\end{tabular}

and carpentering has a very poor physical condition whereas the Pottery and Handloom has comparatively higher values and hence represents the establishment of physical infrastructure for both of their living and enterprise. Handloom has a higher financial capital that plays an important role over the physical capital. On the other hand, Pottery has a lower financial capital but has a moderate value of physical capital due to its establishment period of the homestead.

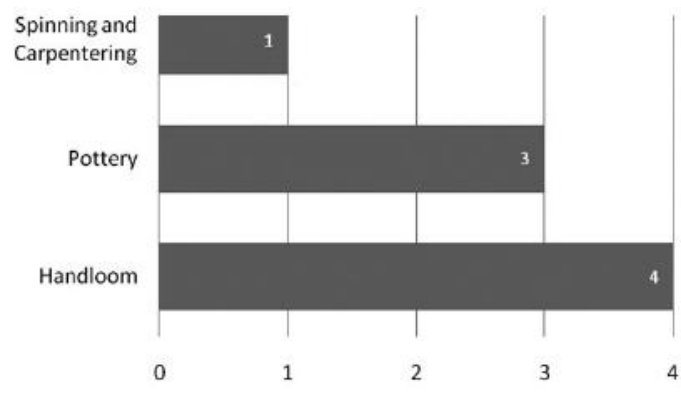

Figure 11. The values of Physical capital in the selected HBE cases in the permanent households

\subsection{Social Capital}

For the HBE of Handloom Sultan has to maintain two types of social networks. These are:

i) Horizontal network - with the local association of similar enterprises. This is to maintain the regular availability of raw materials, rate of raw materials, supply procedure and a uniform rate of workforce.

ii) Vertical network - with the 'paaikar' (whole-seller/ supplier) of raw materials (e.g. shuta and color pigment) to ensure the regular supply chain which is mandatory for regular production. Vertical network with the buyers is also being maintained to disburse the product on a weekly basis.

To operate this enterprise Sultan has to take credit facilities from the suppliers of raw materials. He has to be connected with them with a relationship of trust.

Jon Kumar's homestead and along with its neighborhood are called the 'Kumar Bari' (houses of potters). This kumarbari consists of a total eight homesteads. From ancestry they are engaged with this profession from several generations. They have to maintain a close collaboration with each other not only for the family relationship but also their professional betterment. They have to share many things such as the burner for high temperature burning. Some time they use same transport to carry their product to weekly haat to save transportation cost. As vertical network Jon Kumar has to be connected with the mud supplier and some of his regular buyer like sweet-maker for regular purchase of pots for 'doi' (cart). Sometimes he has to purchase mud as raw material in credit and that is why he has to maintain the relationship 
Table 5. Comparison among the social networks that the HBE cases of Permanent homesteads maintain.

\begin{tabular}{|l|l|l|l|}
\hline $\begin{array}{l}\text { Type of } \\
\text { Social network }\end{array}$ & Handloom & Pottery & Spinning and Carpentering \\
\hline Horizontal network & $\begin{array}{l}\text { With the local association of } \\
\text { similar enterprises. }\end{array}$ & $\begin{array}{l}\text { With the other households of the } \\
\text { kumarbari. }\end{array}$ & No network \\
\hline Vertical network & $\begin{array}{l}\text { With the whole-seller/ supplier of } \\
\text { raw materials and the buyers. }\end{array}$ & $\begin{array}{l}\text { With the mud supplier and some of } \\
\text { regular buyers. }\end{array}$ & $\begin{array}{l}\text { With the employer to collect raw } \\
\text { material and deliver the product. }\end{array}$ \\
\hline
\end{tabular}

with deep trust. Beauty maintains network only with her employer to collect raw material and deliver her product. Shib Shankar has a relation with the timber supplier which is not so strong at all. There is no horizontal network that they maintain. A comparison among the social networks that the selected HBE cases maintain is shown in Table 5. Due to the different levels of involvement with the social networks the values of Social capital in the rating scale fluctuates for the selected $\mathrm{HBE}$ cases in the permanent homesteads. Handloom has the largest value among these three and the Spinning and Carpentering has the smallest.

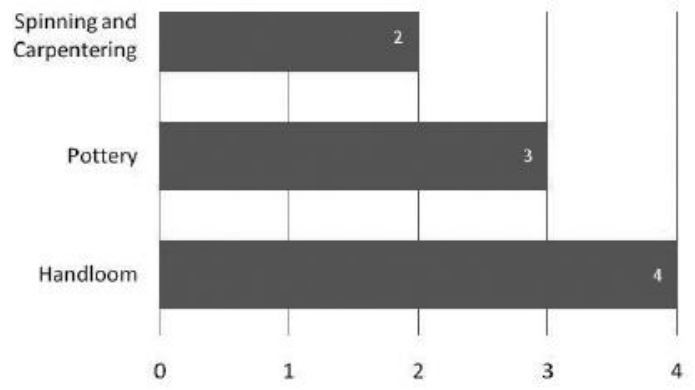

Figure 12. The values of Social capital in the selected HBE cases in the permanent homesteads.

From the above discussion the resultant outcomes in the respective three HBEs of permanent households based on the livelihood capitals are drawn as follows:

Area that are covered by the shaded pentagon represents the total value of the socio-economic living. Besides, the more irregular shaped pentagon makes the sense of the imbalanced relationship among the resources. Among the all three, the pentagon of Handloom is secured by a greatest shaded zone which means their higher value of socio-economic living than the others two. The regular shape of the pentagon reflects the balancing condition of all the capitals. By the interview Sultan Mahamud, the owner of Handloom told about the balancing condition of his household. The income-expenditure balance is one of the major things that he expressed. On the other hand, Spinning and Carpentering has the lowest shaded area for its irregular shaped pentagon that reflects the poor living condition of this household.

\section{Activities and Benefits of HBEs in Floating Households through the Framework of Livelihood Resources}

The selected HBEs in floating households (Table 1) for detail analysis are followings:

\subsection{Human Capital}

In the Egg supply,there are two types of human capital that Mokbul has to operate the HBE. They are:

i) Family members who work without any wages. They work for the betterment of the business as well as of the family. They do not receive any direct wages. Among
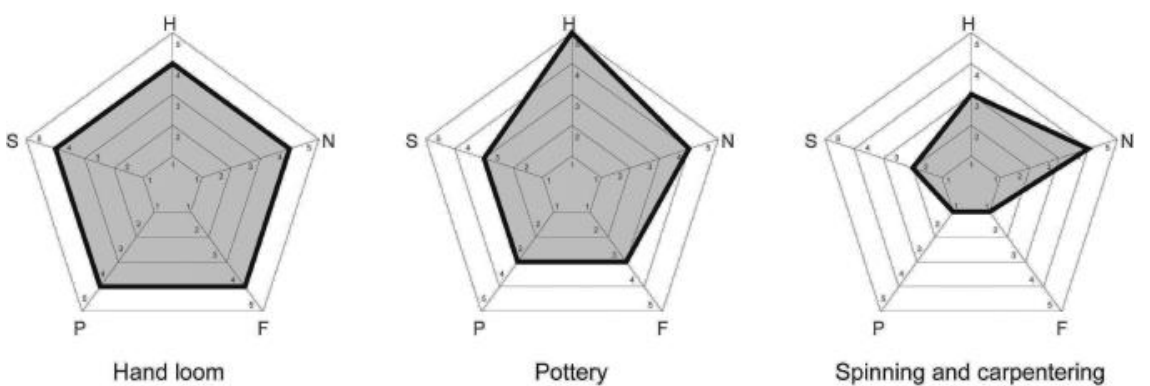

\section{H= Human Capital, N= Natural Capital, F= Financial Capital, $P=$ Physical Capital, $S=$ Social Capital}

Figure 13. The resultant pentagons of three selected cases of permanent households. 
them two are students and they work after their regular school.

ii) People other than the family members who work for wages. Two men work for the HBE on the basis of monthly wages. They are mainly engaged to collect eggs from the local farms.

Azahar has only a single type of manpower for his HBE of Dairy which is the internal manpower from his family. Including himself, his wife, two daughters and one son is involved with the HBE. Family members blend their jobs with the regular household activities. They do not consider any job dedicated to the HBE as any separate entity. Even the cows are also considered as household members. There is no external labour they have for their HBE.

Habibur Rahman himself is the main worker of this HBE of Tailoring. His wife and one of his two sons help him when he needs. His wife has to manage time after the regular household works like cooking, housekeeping, babysitting etc. His son helps him after his school. Both the mother and son developed their skill and trained up with the help of Habibur Rahman. He hires one external labour during the

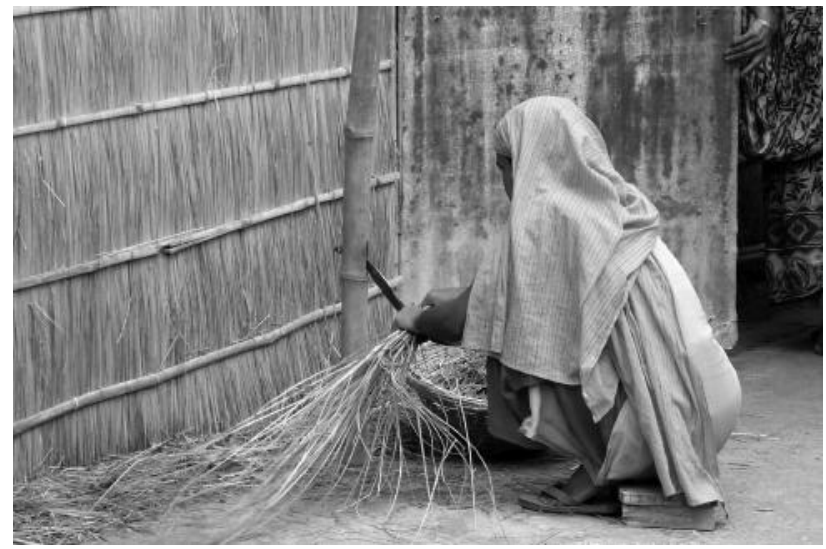

(a) season of Eid (the holy festival of Muslims) when he receives a huge work pressure.

All the selected three cases in floating homesteads are mainly operated by the family members. Only the case of Egg supply has two external labours for its regular works beside the family members' involvement. This is why the value of Human capital of this case is higher in the rating scale than the Dairy and the Tailoring. Total manpower for Dairy is higher than Tailoring but in the rating scale it does not show a higher value than Tailoring (Figure 15). The reason is that the required specific skill for Dairy is lower than Tailoring.

\subsection{Natural Capital}

The HBEs of Egg supply, Dairy and Tailoring are in a region of same natural profile. All of the three homesteads are relatively new in their settlement. All homesteads are more or less five to seven years old in their present location. They were migrated due to the erosion of river Jamuna and resettled in a location which is not so far from the river

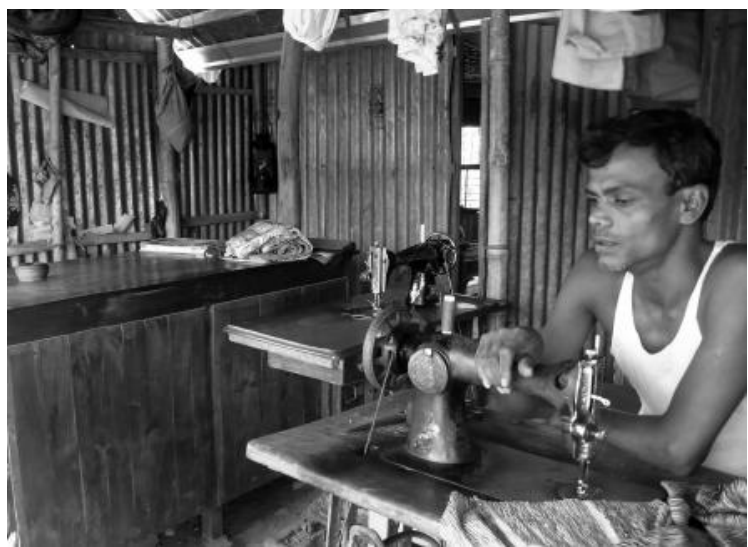

(b)

Figure 14 (a). Female family member is working for the HBE of Dairy and (b): the owner of the HBE of Tailoring is working.

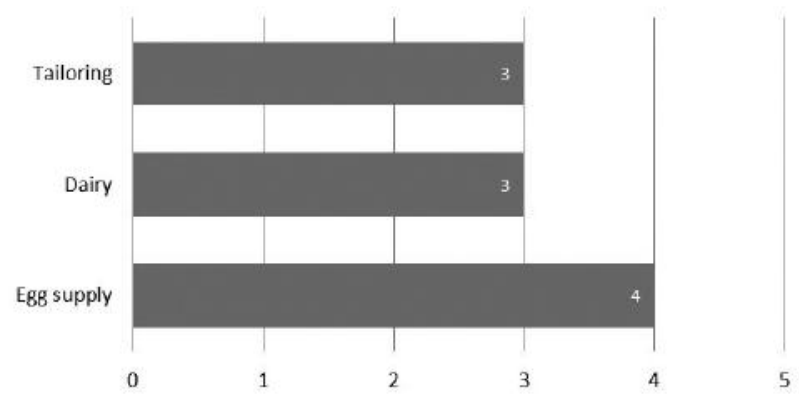

(a)

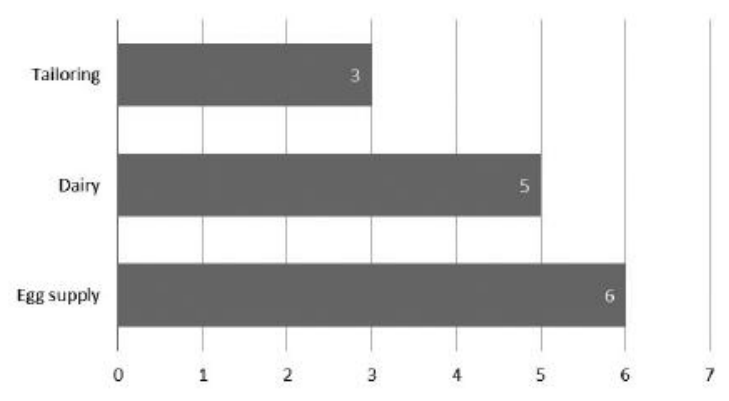

(b)

Figure 15 (a). The values of Human capital and (b): the total manpower engaged in the selected HBE cases in the floating households. 
and these are not permanent as well. They are always in a vulnerable condition and in a threatened situation of river erosion. Besides the second natural threat is the monsoon flood. During flood season the whole village is affected and goes under water.

In the case of Dairy, a major portion of cattle-food comes from the natural fields beside the river which is a natural capital and for which Azahar do not have to pay. Others cases are not directly dependent on any specific natural capital other than air and light. This is why the natural capital is low for every case that has been conducted.

\subsection{Financial Capital}

Two types of stocks that is available for the HBE of Egg supply. They are a) Egg for near about one week's supply and b) Poultry feed that Mokbul supply to the poultry farm. Mokbul has a moderate cash flow status as he has to pay cash to the poultry farm during the time of purchase but he get money from his buyer on a weekly basis. He has an average monthly income of Tk. 12,000 of which $80 \%$ comes from the HBE and other $20 \%$ from the agriculture of their land in the char (river surrounded island). The main stock for the HBE of Dairy is the two cows and two calves. These two milk giving cows are the main asset for the HBE of Azahar. He delivers milk door to door as home service and collect money at the end of the month. Some shops also collect milk from him on cash payment basis. Among this money a major portion is to be used for day to day household expenditure and he has to save a portion for the maintenance of the HBE. When the milk giving period comes to an end the cow has been sold out and a new cow has been bought to replace the old one. For this he creates a savings by sparing some money each month. The average monthly income of this household is Tk. 6,200 of which around $80 \%$ originates from the $\mathrm{HBE}$ and other

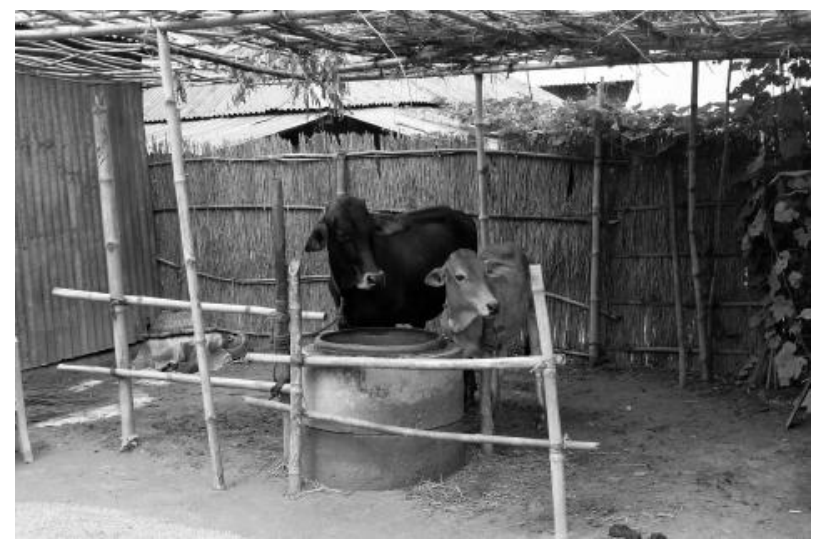

(a)
$20 \%$ from the agriculture of their land in the char which is cultivated by the people who lives in the char.

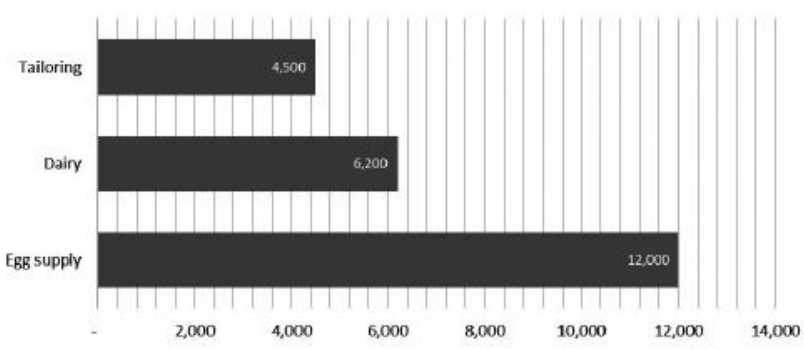

Figure 16. The monthly income (in BDT) in the selected HBE cases in the floating homesteads.

Considering financial asset of Tailoring, Habibur Rahman is a poor owner of his HBE. Three sewing machines is the only stock that he has for his HBE. The cash flow is not so smooth all time of the year. Only during Eid season Habibur receives a good cash flow. Other than that he is a struggler with his business. The average monthly income of this household is only Tk. 4,500 of which around $40 \%$ comes from the land in the char. There is a common feature found by the above discussion that each of the selected HBE cases have cultivable land in char and they get a portion of their earnings from there. These lands are not suitable for living due to insufficient infrastructure and institutional facilities. Some very poor people live there and cultivate the lands and give the portion to the land owner seasonally. Major differences found in financial capital in the three different HBEs shows their financial condition. The monthly income graph shows the financial condition of the selected households. Among the three households, tailoring has the lowest value of Financial Capital with the lowest monthly income and underneath the destitution line considering under 2.00 dollar per day income (World Bank,

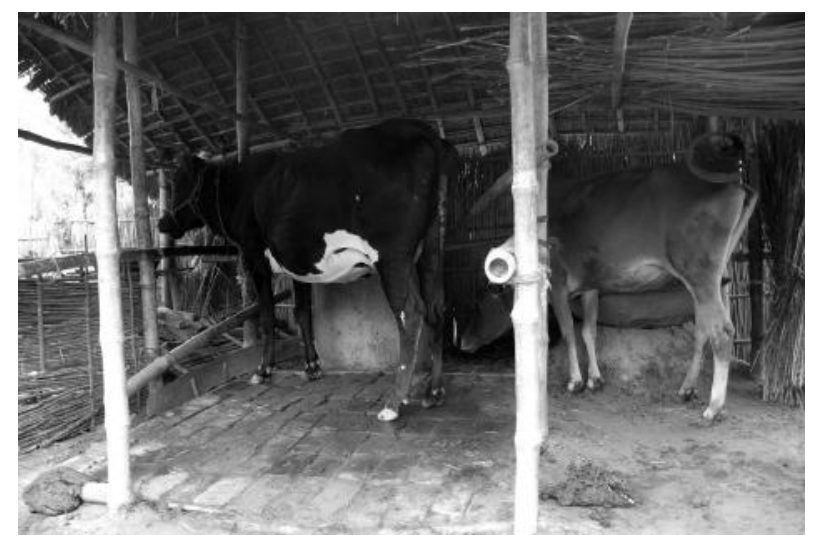

(b)

Figure 17 (a) and (b). The cattle sheds are made of temporary materials in the HBE of Dairy. 


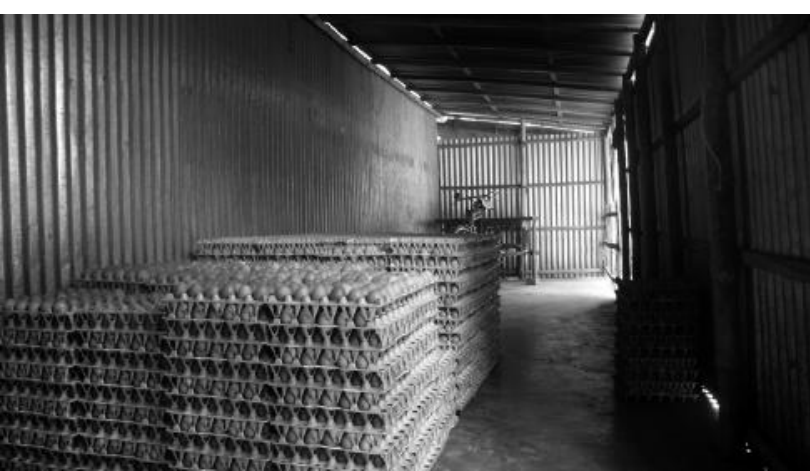

(a)

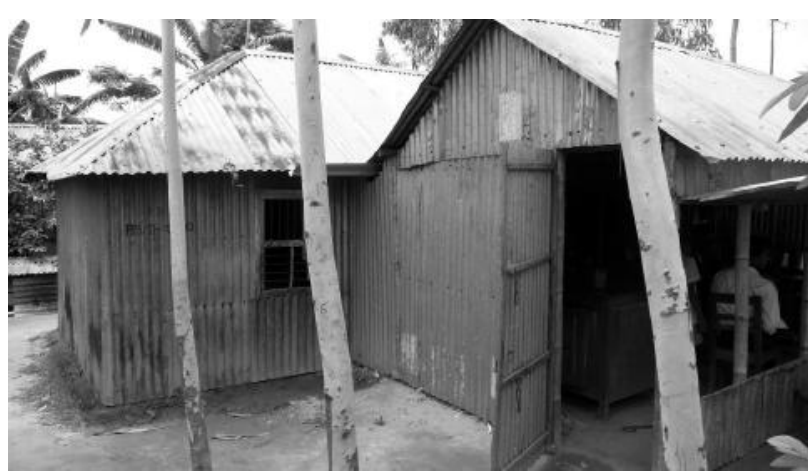

(b)

Figure 18. (a) The elongated shed attached to the house as a shed for Egg supply and (b): The adjacent shed for the Tailoring.

2008). On the other hand, Egg supply has comparatively solvent financial status in the context.

\subsection{Physical Capital}

In the HBE of Egg supply, Mokbul has houses made by CI sheet wall and roof for his homestead and separate shed attached to house for his HBE. The elongated space which was a verandah earlier converted into the storage and delivery space at once. Mokbul use a bicycle to collect eggs from local farms and rickshaw van is used to deliver them to the shops. For water supply a tube-well is there within the homestead for the family use. This homestead has a sanitary latrine for their use. This HBE requires a few amount of electricity which is managed from the home use from the PalliBiddut. The houses and the cattle-shed of the homestead of Dairy are made of temporary materials. They are not established well after their migration due to river erosion.

Table 6. Comparison among the components of Physical capital of the HBE cases of Floating homesteads.

\begin{tabular}{|l|l|l|l|}
\hline $\begin{array}{l}\text { Components of } \\
\text { Physical capital }\end{array}$ & Egg supply & Dairy & Tailoring \\
\hline $\begin{array}{l}\text { Buildings and } \\
\text { settlement }\end{array}$ & $\begin{array}{l}\text { Houses for family and separate shed } \\
\text { for HBE made by CI sheet wall and } \\
\text { roof. }\end{array}$ & $\begin{array}{l}\text { Poor condition of houses. Houses } \\
\text { and cattle shed are made by } \\
\text { temporary materials within a } \\
\text { small piece of land. }\end{array}$ & $\begin{array}{l}\text { House and adjacent shed for HBE } \\
\text { made by CI sheet and temporary } \\
\text { material within a small piece of } \\
\text { land. }\end{array}$ \\
\hline Transportation & $\begin{array}{l}\text { Own bicycle and rickshaw van is } \\
\text { used to collection and delivery. }\end{array}$ & $\begin{array}{l}\text { No vehicular transport for the } \\
\text { HBE. }\end{array}$ & $\begin{array}{l}\text { Transportation is not required } \\
\text { frequently. }\end{array}$ \\
\hline $\begin{array}{l}\text { Water supply and } \\
\text { sanitation }\end{array}$ & $\begin{array}{l}\text { One tube-well for drinking and } \\
\text { daily uses water and one sanitary } \\
\text { latrine for the household. }\end{array}$ & $\begin{array}{l}\text { One tube-well for drinking and } \\
\text { daily uses water and one semi- } \\
\text { sanitary latrine for the household. }\end{array}$ & $\begin{array}{l}\text { One tube-well for drinking and } \\
\text { daily uses water and one semi- } \\
\text { sanitary latrine for the household. }\end{array}$ \\
\hline Affordable energy & $\begin{array}{l}\text { Non-renewable energy from } \\
\text { PalliBiddut for household use. }\end{array}$ & No electricity connection. & $\begin{array}{l}\text { Non-renewable energy from } \\
\text { PalliBiddut for household use. }\end{array}$ \\
\hline Communications & $\begin{array}{l}\text { Cellular phone is used to } \\
\text { communicate frequently. }\end{array}$ & $\begin{array}{l}\text { Cellular phone is used to } \\
\text { communicate. }\end{array}$ & $\begin{array}{l}\text { Cellular phone is used to } \\
\text { communicate. }\end{array}$ \\
\hline
\end{tabular}

A temporary shed without any wall surface is being used for the cows. There is no vehicular transport being used for this HBE. There is a tube-well in this homestead as the source of drinking water and household use and a semi-sanitary latrine for their use. There is no electricity connection to this homestead. Like the HBE of dairy, homestead of tailoring also does not established properly after the migration due to the river erosion. The houses are built with some temporary materials. Habibur has a separate shed attached with the house for his HBE. All are adjusted within a very small piece of land. Electricity is being required to operate one of the three machines of this HBE. The five main components of Physical capital are analyzed with respect to the selected three HBE cases of the floating homesteads in the following table: 
Table 7. Comparison among the social networks that the HBE cases of Floating homesteads maintain

\begin{tabular}{|l|l|l|l|}
\hline $\begin{array}{l}\text { Type of } \\
\text { Social network }\end{array}$ & Egg supply & Dairy & Tailoring \\
\hline Horizontal network & $\begin{array}{l}\text { With similar entrepreneurs to } \\
\text { maintain similar price. }\end{array}$ & No significant network. & No significant network. \\
\hline Vertical network & $\begin{array}{l}\text { With local farmers to collect egg and } \\
\text { to buyer of local markets to sell. }\end{array}$ & With some regular customer. & With some regular customer. \\
\hline
\end{tabular}

It is not so easy to establish proper physical facilities for the HBE or the household in the floating context. Physical establishment requires certain time span on a specific location. In the context of floating households, the homesteads are not old enough to obtain such establishment and that is why the physical capital is generally low in most of the cases. In the case of Egg supply sufficient financial capital helps to establish a comparatively large value of physical capital.

\subsection{Social Capital}

For the HBE of Egg supply, Mokbul has to maintain both horizontal and vertical networks. Downwards vertical network to collect eggs from the local farmers and upwards vertical network for selling them. He maintains horizontal networks to maintain the up to date price of the goods and the business policies. As he does his business with sufficient credit system he has to maintain a relationship with his buyers with trust.

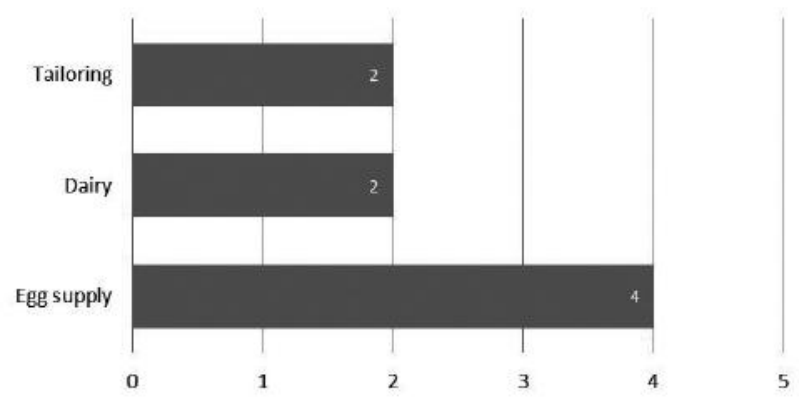

Figure 19. The values of physical capital in the selected HBE cases in the floating homesteads.

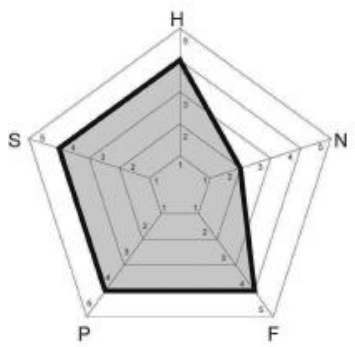

Egg Supply

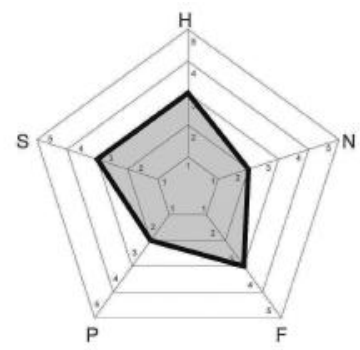

Dairy
Azahar maintains only upwards vertical relation for the HBE of Diary to sell milk. In general, he receives the price at the end of the month, requiring trust towards his client. On the other hand, he has to establish himself to the customers as a trustworthy person which is a must to run his business. Habibur has a vertical network with his customer for Tailoring. Only networks and goodwill can help him to collect customers for his business. Because of his goodwill many people from his old neighborhood give him job but in this village he is a new inhabitant. So he has to create network to collect new customers as well as customers of his old settlement. A comparison among the social networks that the selected HBE cases maintain is shown in the table below. Due to the different level of involvement with the social networks, the values of Social capital in the rating scale varies for the selected HBE cases in the floating homesteads. Tailoring and Dairy has a lower value than the Egg supply.

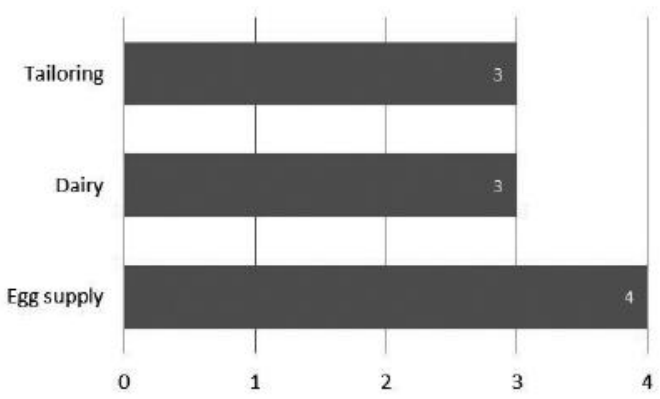

Figure 20. The values of Social capital in the selected HBE cases in the Floating homesteads.

H= Human Capital, N= Natural Capital, F= Financial Capital, $P=$ Physical Capital, $S=$ Social Capital

Figure 21. The resultant pentagons of three selected cases of Floating households. 
From the above discussion the resultant outcomes in the respective three HBEs of floating households based on the livelihood capitals are drawn as follows:

Area that is covered by the shaded pentagon represents the total value of the socio-economic living. Besides, the more irregular shaped pentagon makes the sense of the imbalanced relationship among the resources. Among the above three, the pentagon of Egg supply is covered by a maximum shaded area which denotes their higher value of socio-economic living than the others two. The regular shape of the pentagon reflects the balancing condition of all the capitals. The smaller value of natural capital affects the whole pentagon. On the other hand, Dairy and Tailoring have very similar pentagon other than the financial capital which reflects the poor living condition of these households.

\section{Comparative Socio-economic Benefits of HBEs in Permanent and Floating Households}

Our preceding analyses reveal some differences between the HBE cases of permanent and floating households. The main difference found is the contrasting values of the livelihood resources in the Natural capital. Due to monsoon flood and river erosion, the values of natural capital is significantly low in the case of floating households compared to the permanent households. Considering the financial capital, it is a variable as found through all the cases in both permanent and floating households. Though in both premises high and low values of financial capital is found but if we compare the monthly income of these households a scenario has been come out. The bar of monthly income is a strong consideration for the financial stability of the households.

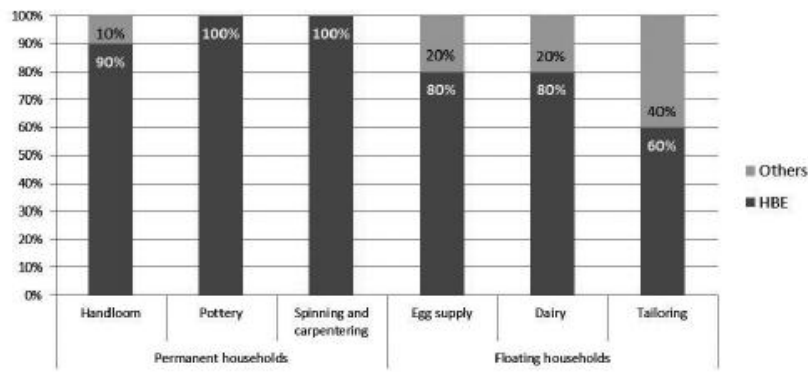

Figure 22. Dependency level of the households on the HBE in permanent and floating households.

It is found that, there are very low level monthly income in some cases of both permanent and floating households such as spinning and carpentering in permanent households and tailoring and basket making in floating households. This represents the financial stability of their business along with the households as well. The dependency of the households on the $\mathrm{HBE}$ can be realized by the percentage of income generating through the HBE. From the field survey it is informed that some households with the HBE like Pottery and Spinning and Carpentering are completely dependent on the $\mathrm{HBE}$ and some are dependent partially. Most of the cases in the floating households have some earnings from the agriculture. Most of them have some agricultural land in char.

The socio-economic benefits of the HBE over the selected households are found by the field survey as the following categories:

- Subsistence: Some of the selected cases are doing HBE for their survival. Pottery and Spinning and Carpentering are such cases of the permanent households and Dairy and Tailoring are the cases of the floating households. They are mainly hardcore poor and need to earn to survive with the basic needs.

- Education: Some cases are found who are managing their children's education expenditure by the HBE. Egg supply, Dairy and Tailoring are the cases from the floating households. Though some of the cases are not so solvent financially they have a strong desire to get their children education.

- Savings: There are HBE cases found, that have sufficient financial support to save money. Handloom is this kind of household in the permanent households. Egg supply is such case in the floating households. They create savings for future. The case of Dairy also creates savings to buy new cow.

- Housing development: The expenditure of settlement and housing is a major consideration for the people of floating households. By the HBE they have to manage this expenditure. On the other hand, it is found in some cases of permanent households that, they develop their houses more.

- Enterprise development:Some households developed their enterprise by the HBE. And it is an ongoing process. For example, the HBE of Handloom expanded his enterprise with more machines to increase the production. The HBE of Dairy has a planning to buy more cows and enlarge his HBE.

- Socialization: Most of the cases of permanent households developed their social status with their HBE by developing their physical and financial condition. In some cases, like Handloom the owners have to maintain wide social network that upraised their social status.

An interpretation among the selected cases for this research can be drawn to understand the socio-economic benefits of them. Asset Pentagon is a graphical representation of the cumulative action of five capitals in a given HBE. The area covered by the shaded pentagon represents the relative performance of the respective HBE. Besides, the more irregular shaped pentagon 
Table 8. Comparison among the asset pentagons of the selected HBE cases.

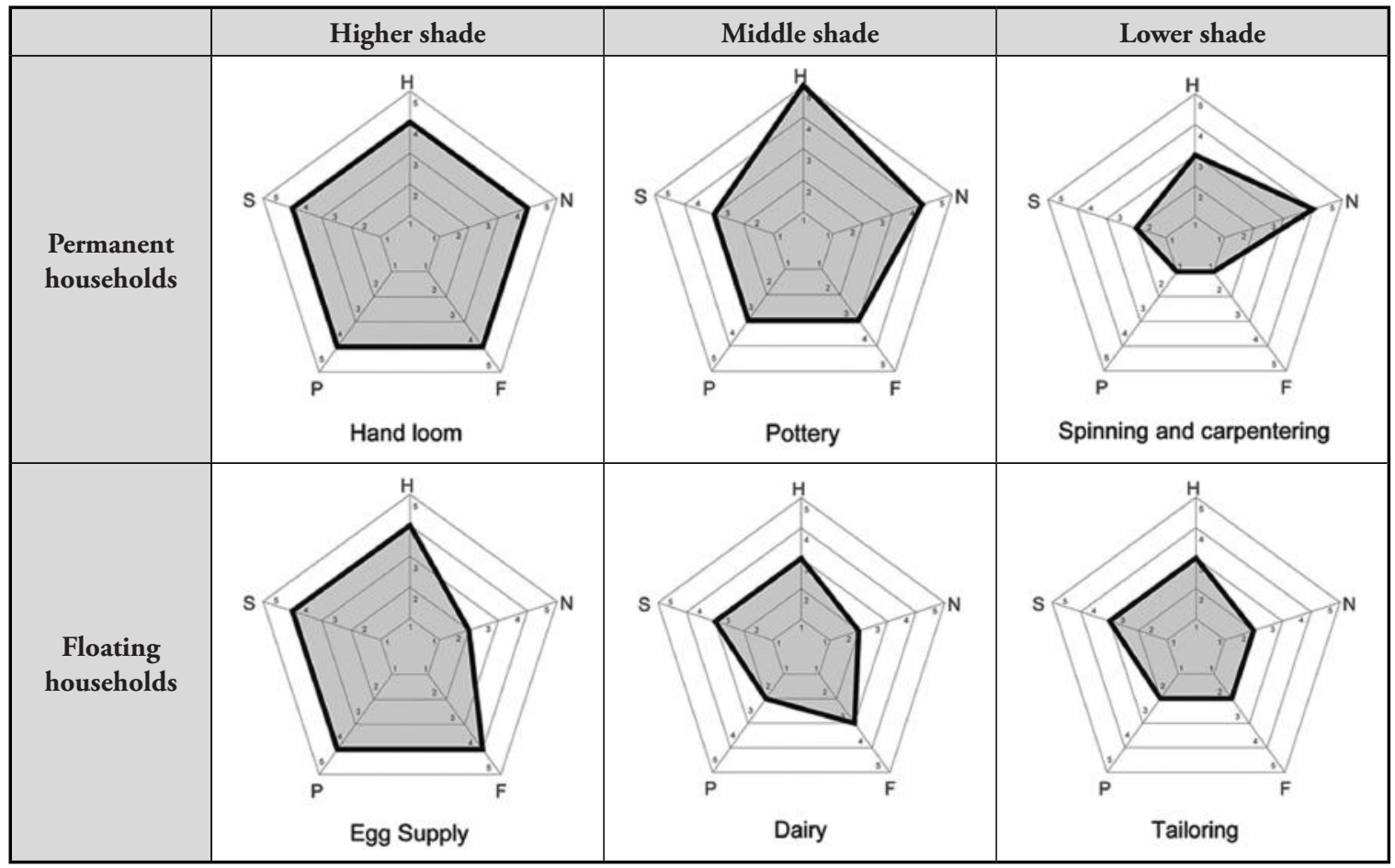

makes the sense of the imbalanced relationship among the resources. Handloom and Egg Supply have the higher shaded area of the pentagon which denotes of having the maximum livelihood capitals. The difference that is shown in Handloom and the Egg supply are in the natural capital. This is because of the threat from the river erosion during the monsoon flood. The Natural capital is the reason of having an irregular shaped pentagon representing the imbalanced situation among all capitals of the Egg supply.

Pottery and Dairy are holding the middle shaded position of their own contexts. But the shaded area of the pentagon shows a big difference between these two cases. Pottery consists of a higher human capital by its experienced and skilled manpower where the Dairy has a moderate human capital like its social and financial capital. The natural and physical capital of Dairy is low because of its poor physical facilities and the threat of the river erosion.

Spinning and carpentering are the cases having the lower shaded area i.e. livelihood resources, in the context of permanent households and the Tailoring is such case in the context of floating households. The deformed shape of the Spinning and carpentering shows the very poor condition of the physical and financial condition of the households. The social capital also has a poor value where the natural capital represents a good and the human capital represents a moderate value of the livelihood resources. On the other hand, Tailoring has a pentagon that represents a balanced situation comparatively. Among the selected cases of the permanent households Handloom has the maximum shaded and proper shaped pentagon which means it is well balanced between all the capitals. Having high human capital Pottery has a low value for the physical, financial and social capitals. Spinning and carpentering has the lowest shaded area that denotes the poor socio-economic condition of this household. In the context of floating households the Egg supply has the maximum livelihood resource that is represented by the shaded pentagon. The Diary and the Tailoring have the same values in all capitals other than the financial capital. Dairy has a higher financial capital than the Tailoring.

\section{Conclusion}

HBEs have been playing a vital role for developing the socioeconomic benefits to the households. Households' livelihood resources such as human, physical, natural, financial and social capital are engaged and affected widely by the HBEs, and on the other hand, the HBEs are also affected by them. The socio-economic benefits of the HBE for all the cases are not same. Some households are practicing HBE only for their subsistence, and some are involved for their household development. Such developments are found frequently in the context of permanent households. In most of the cases of the floating households, HBEs are used to meet the basic needs including their subsistence. In all the cases both in 
permanent and the floating households a major number (in some cases all) of family members are engaged with the HBE. In most of the cases, family members consider their works for $\mathrm{HBE}$ as a part of the household works and thus HBE is an integral aspect of their life and their household.

\section{References}

BBS (2010). Bangladesh Household Survey. Bangladesh Bureau of Statistics, Ministry of Planning, Government of the Peoples' Republic of Bangladesh.

Conway, T, Moser, C, Norton, A \& Farrington, J (2002). Rights and Livelihoods Approaches: Exploring Policy Dimensions, Natural Resource perspectives, The Overseas Development Institute, London.

DFID 1999, Sustainable Livelihoods Guidance Sheets, Department for International Development (DFID), Retrieved on July 1, 2011, from http://www.eldis.org/go/ topics/dossiers/livelihoods-connect/livelihoods-in-dfid

Ghafur, S (1997). Spatial Setting for Homebased Income Generation: The Case of Intermediate- sized Cities, Bangladesh. PhD Thesis. Oxford Brookes University.

Ghafur, S (2001). Beyond Homemaking: The role of slum improvement in home-based income generation in Bangladesh, TWPR, 23, no. 1

Khanam S. (2004). Increasing access to housing for low income people in Bangladesh through income and employment generation. World Urban Forum, Barcelona.

National Agriculture and Forestry Research Institute (NAFRI) (2005). Livelihood Analysis: A Checklist,
Retrieved on March 1, 2011, from http://www. nafri.org.la/document/sourcebook/Sourcebook_eng/ Volume1

Rashid, M. (2013). The Role of Rural Home-Based Enterprises on the Housing Transformation in Sirajganj. M.Arch. Thesis. Bangladesh University of Engineering and Technology, Dhaka.

Rashid, M. (2015). The Changing Patterns of Rural House Form in Floating and Permanent Households in Sirajganj. Journal on Today's Ideas - Tomorrow's Technologies, 3, No. 1, June 2015 1-25, Print Version: ISSN 23213906 Online Version: ISSN 2321-7146

Rashid, M. (2016). Transformation of Spatial Settings of Home-Based Enterprise (HBE) induced Rural Housing in Sirajganj. Protibesh - Journal of the Department of Architecture, BUET, Bangladesh, 15, Issue 1, ISSN 1812-8068. PP36-54 January 2015.

Strassmann, W. P. (1987). Home-based Enterprises in Cities of Developing Countries. Economic Development and Cultural Change, 36, No. 1 (Oct., 1987), 121-144 Michigan State University. Published by: The University of Chicago Press.

Tipple, A. G. (1993). Shelter as workplace: A review of homebased enterprise in developing countries, in International LabourReview, 132, no. 4, 521-539.

World Bank (2008). Poverty data -A supplement to World Development Indicators 2008, The World Bank.

World Bank (2018). Bangladesh Continues to Reduce Poverty But at Slower Pace. World Bank. The World Bank. Retrieved 11 April 2018. 